\title{
GCU
}

Glasgow Caledonian

University

University for the Common Good

\section{Performance standard for tropical outdoors: a critique of current impasse and a proposal for way forward}

Emmanuel, Rohinton

Published in:

Urban Climate

DOI:

10.1016/j.uclim.2017.01.002

Publication date:

2018

Document Version

Author accepted manuscript

Link to publication in ResearchOnline

Citation for published version (Harvard):

Emmanuel, R 2018, 'Performance standard for tropical outdoors: a critique of current impasse and a proposal for way forward', Urban Climate, vol. 23, pp. 250-259. https://doi.org/10.1016/j.uclim.2017.01.002

\section{General rights}

Copyright and moral rights for the publications made accessible in the public portal are retained by the authors and/or other copyright owners and it is a condition of accessing publications that users recognise and abide by the legal requirements associated with these rights.

Take down policy

If you believe that this document breaches copyright please view our takedown policy at https://edshare.gcu.ac.uk/id/eprint/5179 for details of how to contact us. 


\title{
Performance standard for tropical outdoors: A critique of current impasse and a proposal for way forward
}

\section{Rohinton Emmanuel}

Glasgow Caledonian University, Glasgow, UK

\begin{abstract}
Climate change will bring more heat extremes to the already warm tropical areas in Asia, Africa and Latin America. The resulting surge in cooling demand will only make the thermal discomfort in tropical cities even worse. This paper presents evidence to the approaching air conditioned cooling load deluge and shows why the air conditioned management of cooling load is particularly problematic in the tropics. It then presents the technical, institutional and cultural challenges to passive climate-sensitive design in the tropics and posits three ideas as part of the way forward: reformulation of thermal pleasure in the tropics, linking the 'in' and the 'out' at neighbourhood scale and provision of adaptive opportunities varied by activity patterns. Research approaches to advance these ideas are also discussed.
\end{abstract}

\section{Please cite as:}

Emmanuel R, 2017. Performance standard for tropical outdoors: A critique of current impasse and a proposal for way forward, Urban Climate, http://dx.doi.org/10.1016/i.uclim.2017.01.002 


\section{Introduction}

Unusual (> 3 standard deviations [SD] above the base climate of 1951--1980) and unprecedented (> $5 \mathrm{SD}$ ) heat extremes are expected to be the norm in much of Asia and Africa in the near term even as these regions undergo transformational social and economic change (IPCC, 2013). In Sub-Saharan Africa, unprecedented heat extremes are projected over an increasing percentage of land area as global warming intensifies from 2 to $4^{\circ} \mathrm{C}$, resulting in significant changes in vegetative cover and drought events (Lott et al., 2013). In Southeast Asia, heat extremes that are virtually absent at present will cover nearly $60-70 \%$ of total land area in summer, even under a $2^{\circ} \mathrm{C}$ global warming scenario; with $4^{\circ} \mathrm{C}$ global warming, summer months that in today's climate would be termed unprecedented would be the new normal, affecting nearly $90 \%$ of the land area (Sillmann et al., 2013). In South Asia, the situation is even more extreme, irrespective of the global emission paths (Sillmann et al., 2013; Kumar et al., 2010). Reduction in cold days (Yan et al., 2002), increase in both cold and warm tails (Klein Tank et al., 2006), significant increases in the annual number of hot days and warm nights, decreases in cold days and cold nights (Manton et al., 2001; Griffiths et al., 2005) and increases in warm extremes are all likely in much of Asia and Africa.

The most populous parts of these continents are within the Tropical belt (from approximately $23^{\circ} \mathrm{N}$ to $23^{\circ} \mathrm{S}$ of the equator). Consequently, tropical cooling load - much of which is currently latent due to relatively low (albeit rapidly rising) levels of economic development - is likely to be the dominant category of global energy demand (Isaac and van Vuuren, 2009). In the current paradigm, such increases in cooling load could only be met by air conditioning more and more buildings (Davis and Gertler, 2015), exacerbating the warming problem. At the same time, deep technological development and efficiency improvements in cooling systems are yet to be achieved.

To make matters worse, contemporary cultural practices and attitudes limit adaptive possibilities to warmer temperatures as the improving socioeconomic conditions lead to 'thermal indulgence' (Hitchings and Lee, 2008; Han et al., 2009; Indraganti, 2010a; Karyono et al., 2015). There is evidence that long-term exposure to air conditioned environment may even hamper people's physiological acclimatization and weaken thermal adaptability (Yu et al., 2012). Greater use of air conditioning leads to a cycle of cultural dependency, and breaking it appears enormously difficult (Chang and Winter, 2015). One likely outcome of these developments is an unrealistic thermal comfort expectation in the tropics that is in direct conflict with the 'global good' of low/zero carbon economy. A compromise has to be reached between societal priorities and personal desires to ensure lowest energy expenditure without confining tropical dwellers to an 'inferior' thermal comfort.

This paper presents evidence to the approaching air conditioned cooling load deluge in light of the changing climate made worse by urbanization, critiques the current inability to effectively deal with the problem and proposes a new way of managing the cooling load deluge by 'climate-sensitive commons.' The Background section presents six reasons why the cooling load problem in the tropics is unique and in need of new thinking. In light of these, three ideas are put forward for future urban climate-sensitive design in the topics. Finally, five research and knowledge transfer needs are posited as necessary to realise these design ideas.

\section{Background}

Much of the climate change risks in the tropics are concentrated in urban areas. These include rising sea levels and storm surges, heat stress, extreme precipitation, inland and coastal flooding, landslides, drought, increased aridity, water scarcity and air pollution (Revi et al., 2014). Given the current level of urban growth and the concentration of populations involved, climate change will 
interact with the urban risks in a variety of ways, some of which will exacerbate the level of climate risk (IPCC, 2013). Furthermore, there are health inequalities, especially in developing cities that are further exacerbated by urban warming (cf. Campbell-Lendrum and Corvalán, 2007).

However, research on the augmentation of climate change effects by local urban warming (characterised by urban heat islands) remains weak. Initially, even the Intergovernmental Panel on Climate Change (IPCC) overlooked the role of cities both as a forcing factor as well as a key stakeholder in managing climate change (Hebbert and Jankovic, 2013). Additionally, translating future climate change projections at finer spatial scales relevant to cities typically use statistical downscaling techniques to global climate models without modelling the urban areas themselves (Lemonsu et al., 2013). Furthermore, the practical implementation of the limited urban warming knowledge is rare.

But things are changing: urban heat island mitigation is explicitly mentioned in IPCC AR5 Working Group 3 Chapter 9 (Lucon et al., 2014). Explicit connections between climate change and action in cities is increasingly being made (for example, Rosenzweig et al., 2015). Tools and strategies to evaluate the effectiveness of heat island mitigation measures, such as the Comprehensive Assessment System for Building Environmental Efficiency - Heat Island Tool (CASBEE-HI http://www.ibec.or.jp/CASBEE/english/overviewE.htm) have been proposed. However, the amelioration of the heat island effect in the urban tropics is particularly weak. On the one hand, knowledge of tropical heat islands remains patchy and numerically weak (cf. Hung et al., 2006; Roth, 2007). On the other, the proliferation of strategies focusing on heating-only climates (or the dualmode heating-and-cooling load climates) does not readily translate to cooling-only regions

\subsection{Uniqueness of cooling load}

The task of cooling is very different from the act of heating due to physical, social and economic reasons. A key difference between heating and cooling is in the respective load structures. Cooling requires the tackling of the increases in both the sensible as well as the latent loads (Kalvelage et al., 2014). In the humid tropics, this would translate to dehumidification and cooling, doing both of which without over-compensating for one or the other is extremely challenging (Sekhar, 2016).

Second, increased use of air conditioning in a warming world will only make the urban situation worse. While on the one hand temperature rise would lead to greater use of air conditioners (e.g. for every $1^{\circ} \mathrm{C}$ rise ambient temperature rise, the electricity consumption in Hong Kong was estimated to increase by $9.2 \%, 3.0 \%$, and $2.4 \%$ in domestic, commercial and industrial sectors, respectively - Fung et al., 2006) a recent study in Malaysia found that every $1^{\circ} \mathrm{C}$ increment in outdoor temperature will cause a $2 \%$ drop in the coefficient of performance of split-type air conditioners (Yau and Pean, 2014). This is in sharp contrast to heating in urban areas, where, wasted heat tends to reduce the heating load for surrounding buildings (Futcher et al., 2013). The current increase in temperature due to air conditioner use was estimated to be $0.5^{\circ} \mathrm{C}$ but could be up to $2^{\circ} \mathrm{C}$ if the air conditioner use is to double (de Munck et al., 2013: 210).

Third, even when run on fossil fuels, heating could be provided by a variety of fuels (gas, oil, etc.) that have lower carbon footprints than electricity (especially coal-fired electricity) which is the predominant source of power for most air conditioners. Thus, even a small increase in cooling load could vastly inflate global carbon emissions.

Fourth, much of the global heating demand is already manifest while much of the cooling demand is still latent. Ürge-Vorsatz et al. (2015) found that regions dominated by heating load will see reduced or stagnant growth in energy use while warm regions dominated by cooling load will see exponential increase in cooling loads (see Figure. 1 and Table 1). This will be further exacerbated by trends within countries with heating and cooling demand - for example, USA (Kalvelage et al., 2014) where 
heating demand is expected to decrease while cooling demand will soar. Currently heating load dominated countries too, are expected to have significant cooling loads in the coming decades.

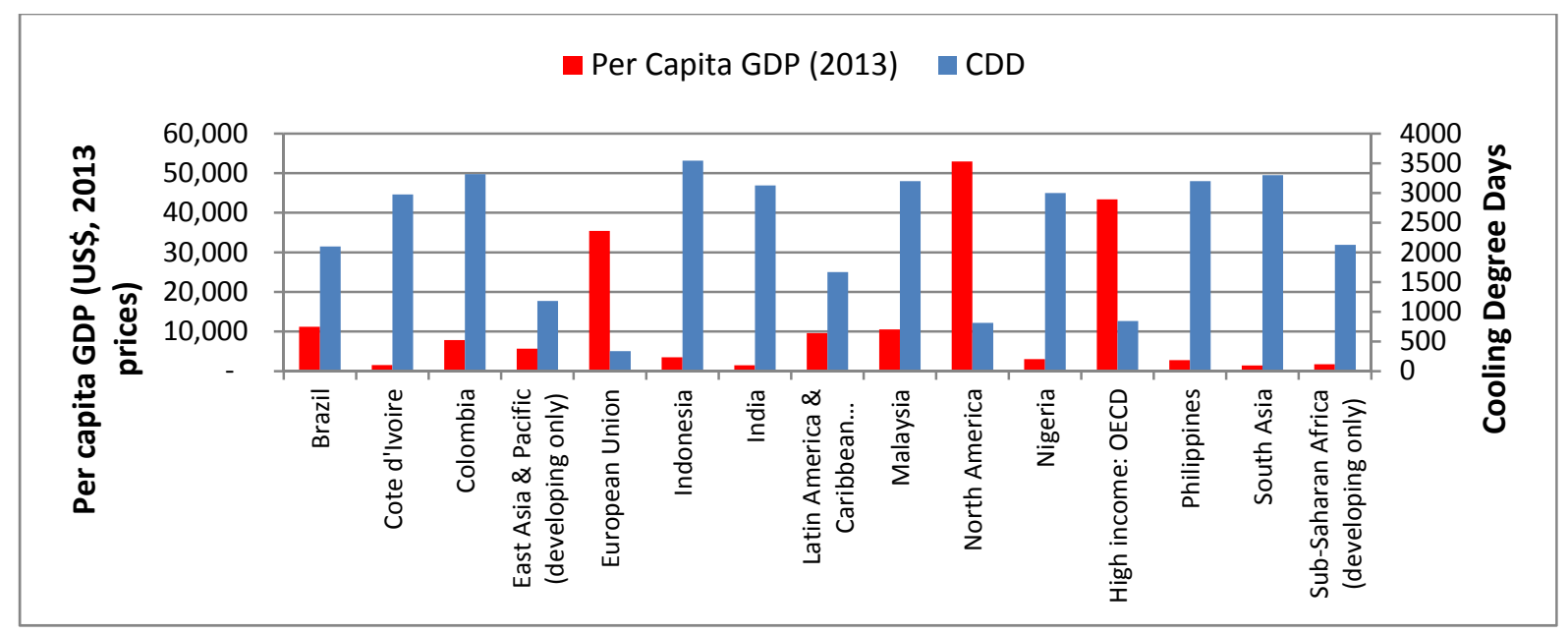

Figure 1 Income vs cooling load comparison (Source: Emmanuel, 2016)

Table 1 Trends in global residential space heating and cooling demand $\left(\mathrm{kW} / \mathrm{m}^{2}\right)$ (Source: Ürge-Vorsatz et al., 2015)

\begin{tabular}{|c|c|c|c|c|c|}
\hline & 2010 & 2020 & 2030 & 2040 & 2050 \\
\hline Pacific OECD ${ }^{1}$ & 126.1 & 122.4 & 119.1 & 116.0 & 113.4 \\
\hline N America & 147.5 & 138.4 & 131.0 & 124.9 & 119.7 \\
\hline W Europe & 128.3 & 123.1 & 118.4 & 114.2 & 110.4 \\
\hline Central \& E Europe & 152.6 & 148.1 & 144.8 & 141.8 & 139.1 \\
\hline Former Soviet Union & 205.1 & 198.4 & 194.5 & 191.6 & 189.0 \\
\hline Latin America & 63.3 & 60.2 & 59.5 & 59.3 & 59.6 \\
\hline Sub-Saharan Africa & 56.2 & 53.4 & 52.9 & 53.0 & 53.4 \\
\hline Middle East and N Africa & 55.6 & 55.1 & 56.0 & 57.4 & 58.0 \\
\hline Centrally Planned Asia ${ }^{2}$ & 37.4 & 41.2 & 43.8 & 46.8 & 47.5 \\
\hline South Asia & 60.1 & 77.1 & 85.0 & 89.2 & 88.2 \\
\hline Other Pacific Asia ${ }^{3}$ & 46.4 & 45.5 & 45.6 & 45.9 & 46.5 \\
\hline
\end{tabular}

Note (see http://www.iiasa.ac.at/web/home/research/researchPrograms/Energy/MESSAGE-model-regions.en.html for naming conventions of world's regions)

${ }^{1}$ Australia, Japan, New Zealand

${ }^{2}$ Cambodia, China (incl. Hong Kong), Korea (DPR), Laos (PDR), Mongolia, Vietnam

${ }^{3}$ Southeast Asia and the Pacific Island states

Fifth, cooling itself is potentially more harmful from a global warming perspective than heating in that the refrigerants used in the process (mostly hydro-fluorocarbons - HFCs) have greater global warming potential than $\mathrm{CO} 2$. HFCs" contribution to global warming, much of which is from air conditioning and refrigeration, is expected to be 9--19\% (CO2 equivalent basis) of global $\mathrm{CO} 2$ emissions in 2050 under business-as-usual scenario (Velders et al., 2009).

Finally, while the physics and the practicalities are more complex than heating, cooling - especially the mechanised variety - is also harder to divest of, given its social construct. The comfort of 'coolth' is often seen as a sign of progress, initially a sign of luxury but eventually, the fulfilment of desire. Heating does not have this association with 'luxury' since warmth was always seen as a primordial need (cf. Sivak, 2009). 
The association between 'coolth' and luxury or progress is not unique to the tropics: there is evidence (e.g. Ackerman, 2002) to such association in the United States during the early years of the introduction of air conditioners. However, what is unique about the tropical cooling load and its association with luxury is the scale of the cooling challenge made all the more pressing by the rapid economic progress currently underway in the region and the size of the tropical population that will demand greater cooling in the years to come.

\subsection{Current impasse in climate-sensitive design in the tropics}

In spite of the changes to tropical climate both at global/regional level as well as at city level there is little evidence that climate sensitive design has received any greater attention than it had ever had. Three broad categories of barriers need to be overcome to enhance the reputation of passive climate-sensitive design and embed it into everyday urban life: technical, institutional and cultural.

\subsubsection{Technical}

Climates with clear seasonality have the possibility to control the indoors at building envelope level, by a clear separation of the 'in' from the 'out.' However, given the relatively small deviation of typical outdoor temperatures from the comfort range, tropical building envelopes are more porous; the 'in' and the 'out' are often indistinguishable. But this would only work if the outdoor conditions are close to the comfort range. The crux of the problem is that tropics (especially the urban tropics) have warmed to an extent that passive, building-level strategies that benefit from porous building envelopes (such as cross ventilation and nighttime cooling) are unable to provide adequate comfort by themselves. . Such passive 'traditional' approaches to climate-sensitive design appears less effective under a changing and extreme climate (Nguyen et al., 2011) especially in urban areas (Pozas and González, 2016; Rubio-Bellido et al., 2015; Foudazi and M'Rithaa, 2013). In other words, the passive climate-sensitive design options at the building level are approaching the technical limits of low energy design in the tropics, as the background climate continues to warm. We need agreement on the 'what' (i.e. the scope) of climate-sensitive design.

\subsubsection{Institutional/governance issues}

Equally importantly, the 'how' of climate sensitive design, too, needs attention. Urban design, unlike the design of individual buildings, concerns that which belongs to all and is therefore subject to the 'tragedy of the commons' (Hardin, 1968). The promotion of good urban design therefore needs strong institutional underpinning. On its own, climate sensitive design lacks the clout and capacity to grab and hold the attention of key decision makers. This is especially the case in tropical cities where the problem of overcrowding and the more immediate risks associated with climate-change (such as flooding, coastal erosion, dust storms and drought) are ever more pressing. Overcrowding in particular leads to smaller building plot sizes, resulting ever so diminishing ability to cool buildings due to the thermal interference of neighbouring structures. The embedding of climate sensitive design into everyday planning decisions will be important to success. However, climate-sensitive planning is scale-dependent and needs to be linked to the broader urban sustainability agendas such as poverty alleviation, economic development and urban regeneration (Mills, 2006; Georgescu et al., 2015).

Furthermore, innovative institutional arrangements are needed to link on-the-ground scientific expertise to the needs and requirements of local decision-makers at city level (cf. Rosenzweig et al., 2010). Planned eco-cities (such as the Marina Bay Financial Centre district in Singapore https://www.ura.gov.sg/uol/master-plan/View-Master-Plan/master-plan-2014/master-plan.aspx) provide early examples of such innovative and integrated institutional arrangements. Additionally, the governance arrangements in cities too need consideration: who will champion climate-sensitive design? Whose priorities are dominant in urban contexts; and what are the implications of this to climate sensitive design? Finally, how 'autonomous' are cities in being able to chart their own adaptation destiny? 


\subsubsection{Cultural barriers}

"The most important point is that even the most tradition-minded, nature-oriented or environmentally-concerned family would have difficulty living in a modern Trivandrum (capital of humid tropical Southern Indian State of Kerala) home without airconditioning. (Wilhite, 2009, p. 193)"

Perhaps the greatest challenge to climate-sensitive design in the tropics is cultural. Openness to passive climate sensitive design depends on the socioeconomic status. Those who can afford the energy expenditure on air conditioning tend to be 'thermally indulgent' to the point of low tolerance for thermal displeasure (Indraganti, 2010a). This leads to what Chang and Winter (2015) called 'Thermal modernity.' Additionally, cultural practices and preferences/attitudes lead to "restrained adaptive opportunity" (Indraganti, 2010b), resulting from the way alternate choices are presented and made possible (Wilhite, 2009). Examples of such cultural practices and preferences include the practice of air conditioning all public places (Hitchings and Lee, 2008), increased indoor dwelling as climate warms (Zivin and Neidel, 2014), enjoying the cool comfort of excessively cooled shopping malls in India and Singapore (Chua, 2003) and winter wear in Singapore as 'culturally expressive forms of clothing' (Hitchings and Lee, 2008).

As tropical countries continue their march towards 'middle income' status greater comfort is demanded by more and more of their citizens. An immersion in greater comfort (i.e. greater pleasure) appears to hyper-sensitize humans to a point of inability to cope with natural variations in temperature. While the use of air conditioning undoubtedly leads to 'superior' comfort (and has come to be seen as a sign of 'progress' in the tropics - see, Lee, 2009) it also diminishes the coping mechanisms of tropical dwellers.

Climate-sensitive design could help, but, unfortunately it had hitherto largely remained an elite project in the tropics, where the vast majority of buildings continue to be relegated to the intolerable-to-barely-passable margins. No context exists for the enjoyment of an otherwise pleasant climate by a majority of citizens.

\section{Where do we go from here?}

It is said that thermal comfort (in temperate climates) needs to be 're-contextualised' in light of climate change (Cole et al., 2008). This often means a more inclusive, inhabitant-controlled, flexible notion of thermal comfort that allows for 'inhabitant agency' (Cole et al., 2008) but questions remain as to its applicability in the high-density, rapidly growing and generally resource-poor urban tropics. The nature of tropical thermal comfort, especially in light of changing urban climate, is not always achievable even with 'inhabitant agency,' at least not most of the time. What therefore must we do in the tropics?

Creating a climate-sensitive urban realm is a strong possibility in the tropics that would enable the 'conditioning' of individual buildings easier. Thus it is proposed that the changing tropical climate, especially in the cities could only be made comfortable (and places for human thriving) by climatesensitizing the urban realm. It is not expected that doing so will eliminate the need for air conditioning. Far from it; climate- sensitive urban design is a crucial enabler of outdoor living, even in the face of climate change. This could create the condition for alternate ways of enhancing urban quality of life while individual buildings may or may not need additional coolth.

This endeavor is wider than what a planning or an urban design remit would allow. We need a new way of being, which has implications to the way tropical dwellers perceive clothing, furniture, food and indeed their bodies. While this is far too wide a subject to be covered in this paper, three ideas are posited as central to the achievement of thermal comfort in the tropics as a starting point for climate-sensitive design: 
Reformulation of thermal pleasure in the tropics.

Linking the 'in' and the 'out' at neighbourhood scale.

Provision of adaptive opportunities varied by activity patterns.

\subsection{Reformulation of thermal pleasure in the tropics}

Thermal pleasure in a hot environment is very different to that in a cold environment: coolness is only 'skin deep' (i.e. we feel evaporative and convective cooling on the surface of the skin, as opposed to warmth, which is internal - cf. Heschong, 1979). It is also about calming the senses in a highly- (almost over-) simulated environment where deep shade, vegetation and water individually or collectively play a role in creating a serene and calming effect.

At the heart of this formulation of thermal pleasure is an urban asymmetrical thermal environment dominated by cool spots that enables greater enjoyment of the outdoors - a form of spatial alliesthesia (Parkinson and de Dear, 2015), thus enabling low-energy cooling in the indoors. An urban asymmetrical thermal environment could be achieved in a number of different ways, all aiming to create climatically 'cool' urban public spaces:

Partially shaded pathways.

Strategically placed and adequate vegetation cover.

Water misting (see Emmanuel, 2016 for further details).

\subsection{Linking the 'in' and 'out' at neighbourhood scale}

The achievement of thermal comfort in the tropics is about the "integration of microclimate, form and fabric of the building" (Rajapaksha and Hyde, 2012). Air conditioning leads to "hardening of the physical and social boundaries between home and surroundings" (Wilhite, 2009). Substantial improvement in indoor thermal comfort is possible only if efforts to do so begin at the neighbourhood scale (i.e. outside the building). Examples of linking the 'in' and the 'out' at neighbourhood scale include, arcaded street fronts wrapping around all building in an urban block, tree-lined building frontage that act a porous intermediary between the 'in' and the 'out' and shading of the interstitial spaces by a juidicious combination of three-dimensional geometry of buildings and their solar orientation (as exemplified by the 'shadow umbrella' concept - Emmanuel, 1993). Such manipulation of settlement geometry, street orientation and external factors such as street trees create 'environmental diversity' (Steane and Steemers, 2004) that would be central to achieving thermal comfort in the tropics by climatically linking the inside of buildings with the outside.

The linking of the 'in' and the 'out' ought to reflect the purpose for which thermal comfort standards are being promulgated. Lenzuni et al. (2009) suggest differentiation of thermal standards along the following: the subject's thermal sensitivity, accuracy required for carrying out the task and the practicality of thermal control. We suggest a fourth, the difference between the indoor and the outdoor conditions that need to be achieved.

\subsection{Provision of adaptive opportunities varied by activity patterns}

Given the year-round possibility to use tropical outdoors for daily living, urban thermal comfort gains greater importance in the overcrowded tropics where room occupancy rates are unhealthy (cf. Correa, 1989). A critical need is to specify outdoor thermal standards in terms of urban activities that facilitate comfortable movement in the outdoor, leading to higher quality-of-life. (See Fig. 2) 

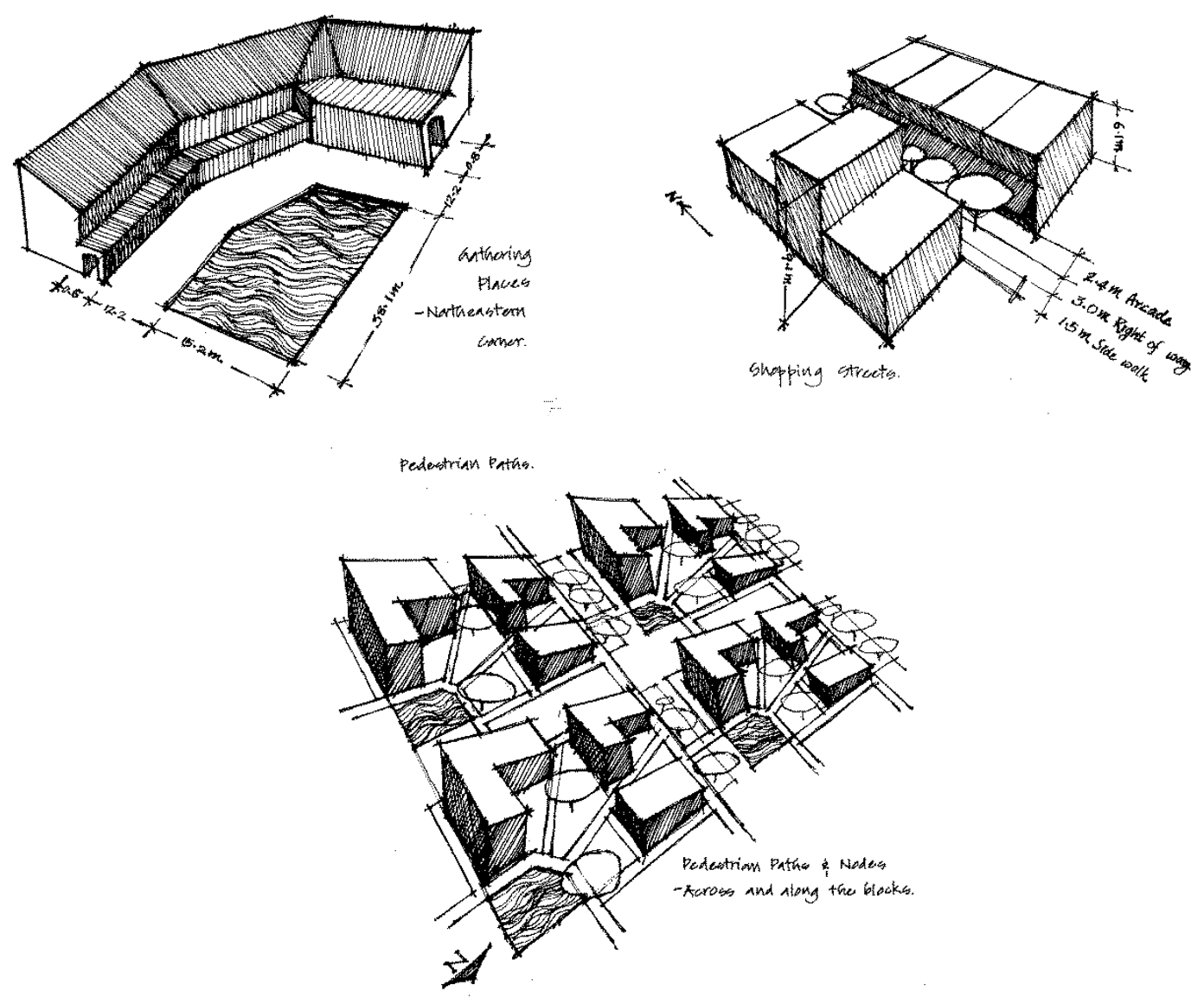

Figure 2: Conceptual sketches outlining (a) Gathering places, (b) shopping streets and (c) pedestrian paths and nodes that also facilitate evening life (Source: Emmanuel, 2005)

Such extension to the comfort zone could be greatly facilitated by the provision of adaptive opportunities that are organised around activity patterns of tropical urban life. Emmanuel (2005) suggested four such adaptive opportunities organised around tropical activity patterns (Figure 2):

a. Shopping Streets - create canyon-like shopping streets, where the street itself is north/south running, with buildings on the west being slightly taller than those on the east. Line both facades of street-facing buildings with arcades, so as to provide adequate protection from rain and sun.

b. Gathering Places - surround urban waterbodies with a built form edged by arcades. Locate public activities along the arcade, overflowing into the commons. Dissuade all activities that do not directly benefit from water's edge from locating on urban waterfronts.

c. Provisions for evening life - Evenings are tropics' winter (Rao, 1981). Street corners are especially attractive to be incorporated into the evening life, particularly if they intersect northerly and easterly orientation.

d. Pedestrian Paths and Nodes - Establish a network of pedestrian links independent of city street network. Paths within city blocks could be the primary carriers of cool air (say from a pond). Wherever the pedestrian path crosses the vehicular path, establish a place to pause. 


\section{Research and knowledge transfer needs}

Before the above three are given concrete urban form, it is necessary to conduct further research on the tropical urban warming problem. These pertain to "data, technical and scientific needs" (such as relative merits of shade vs. ventilation to tropical thermal comfort), "socio-physiological and habitual needs" (such as thermal comfort in the outdoors, performance standards for different activity patterns) and "political and institutional needs" (implementation and monitoring, urban climate $\leftrightarrow$ global climate feedback):

\subsection{Shade vs ventilation}

The cooling effect of ventilation in the tropics is now part of the conventional wisdom. What is not well acknowledged are the thermal comfort effects of wind in a warming city. The combined radiant cooling effect of shade together with the convective cooling of wind on tropical thermal sensation needs further systematic study. The seasonality of wind (as affected by the monsoons) in conjunction with the annual variations in temperatures (highs coinciding with weak wind patterns due to the passage of inter tropical convergence zone) needs to be reflected in field studies. The substantial body of research on shade-oriented planning in hot, dry climates and the knowledge of wind in hot, humid climates need to be brought together to understand the practical possibilities of both, in ways similar to that attempted by Balslev et al (2015).

\subsection{Thermal comfort in outdoors with a variety of morphologies}

Closely related to this is the collection of empirical evidence to the effect of a variety of urban morphologies on outdoor comfort in the urban tropics. This would benefit from a standardization of measurement protocols for outdoor comfort (cf. Johansson et al., 2014). A key requirement is the accurate estimation of Mean Radiant Temperature $\left(T_{M R T}\right)$ which is more critical in a warm, humid context than in a cold, dry one. Integral radiation measurements and the calculation of angular factors as proposed by Thorsson et al., 2007 is needed. Johansson et al., (2014) provide a comprehensive overview of the many techniques to measure $T_{M R T}$.

\subsection{Performance standards by activity patterns/land use}

The above two areas of research should lead to performance standards for outdoor urban spaces. As discussion in Section 3, it would be ideal if these could reflect the many activity patterns appropriate for tropical cities and highlighted in the discussions above.

\subsection{Neighborhood scale implementation and monitoring}

Ultimately, the proof of the pudding is in the eating. A considerable body of knowledge already exists on approaches based on tropical ventilation ( $\mathrm{Ng}, 2016)$, shade (Lin, 2016) and vegetation (Duarte, 2016). Both traditional settings and 'new towns' developed post WWII could be ripe for empirical measurements of outdoor thermal comfort conditions under these three approaches in the tropics.

\subsection{Urban climate amelioration and regional climate feedback}

As tropical cities grow (and turn into megapolii) more direct feedback between urban land-cover and regional and perhaps global climate may be foreseen. Although cities currently occupy only a tiny fraction of global land cover this may change dramatically in the tropics so as to have a regional climate impact. The climate transformation of Pearl River Delta is a case in point (Wang et al., 2014). It is necessary to study such regional feedbacks in greater detail. However, the notoriously wicked problem of reliable land use/land cover data in the topics need to be tackled first. In this regard, current initiatives such as the World Urban Database and Access Portal tools (WUDAPT, See et al., 2015) and land use/land cover parameterization schemes such as Local Climate Zone (LCZ, Stewart and Oke, 2012) could offer promising head start. WUDAPT is a community-driven initiative amassing data on urban form and function to help cities worldwide to develop their own heat-adaptation 
plans. This could provide a standardized characterization of the world's major cities and detailed input data for urban climate models. Application of a version of LCZ for data-poor tropical cities has been recently demonstrated (Perera and Emmanuel, 2016).

\section{Concluding remarks}

Amelioration of UHI provides a local narrative within which strategies for the enhancement of urban quality-of-life can find acceptance and even active support. A political difficulty with action against global climate change is the inability to see results in the here and now. Tackling the urban climate change offers immediate and tangible benefits since the negative consequences of haphazard urbanization is plain to see. This is increasingly being recognised in international efforts. Examples include greater focus on urban climate by the World Meteorological Organisation (such as the "WMO Urban Agenda" - http://public.wmo.int/en/our-mandate/focus-areas/urban-developmentmegacities/wmo-and-new-urban-agenda); World Health Organisation"s (WHO) greater attention to public health - especially ageing in the changing climate (http://www.who.int/globalchange/en/). and UN-Habitat III's smart city and quality of life agenda (http://unhabitat.org/wpcontent/uploads/2015/04/Habitat-III-Issue-Paper-21 Smart-Cities-2.0.pdf). Rapidly growing tropical cities need to participate in such international efforts to enhance their local environmental conditions even as they contribute to the global climate change adaptation agenda. Experience gained in such endeavours could enable tropical cities to positively contribute to the two-way knowledge transfer (between the developed and developing worlds) of living in a warming world.

\section{References}

Ackerman M.E. 2002. America's Romance with Air-Conditioning, Smithsonian Institution Press, Washington, D.C.

Balslev Y.R., Potchter O, Matzarakis A. 2015. Climatic and thermal comfort analysis of the Tel-Aviv Geddes Plan: A historical perspective, Building and Environment, 93, Part 2, pp 302-318

Campbell-Lendrum D, Corvalán C. 2007. Climate change and developing-country cities: Implications for environmental health and equity, Journal of Urban Health, 84, 1, i109-i117

Chang J-H. and Winter T. 2015. Thermal modernity and architecture, The Journal of Architecture, 20(1), 92-121, http://dx.doi.org/10.1080/13602365.2015.1010095.

Chua, B.H. 2003. Life Is Not Complete Without Shopping: Consumption Culture in Singapore. Singapore: Singapore University Press

Cole RJ, Robinson J, Brown Z, O'shea M, 2008. Re-contextualizing the notion of comfort, Building Research \& Information, 36, 323-336

Correa, C., 1989. The New Landscape: Urbanization in the Third World, London: Butterworth Architecture

de Munck C, et al., 2013. How much can air conditioning increase air temperatures for a city like Paris, France? International Journal of Climatology, 33, 210-227

Davis L.W., Gertler P.J. 2015. Contribution of air conditioning adoption to future energy use under global warming, PNAS, 112, 19, pp. 5962-5967

Duarte DHS. 2016. "Vegetation and climate-sensitive public places," In, R Emmanuel (ed.), Urban Climate Challenges in the Tropics: Rethinking Design Opportunities, London: Imperial College Press, pp. 111-162 
Emmanuel R, 1993. A hypothetical 'shadow umbrella' for thermal comfort enhancement in the Equatorial Tropical urban outdoors, Architectural Science Review, 36(4): 173-184

Emmanuel R, (ed.). 2016. Urban Climate Challenges in the Tropics: Rethinking Design Opportunities, London: Imperial College Press

Emmanuel R, 2005. An Urban Approach to Climate Sensitive Design: Strategies for the Tropics, London: E\&FN Spon Press

Foudazi F, M'Rithaa M. 2013. Sustainable cooling solutions for application in Western Cape Province, South Africa, Int. J. of Sustainable Development, 16, 3/4, pp.246 - 268

Fung W.Y., Lam K.S., Hung W.T., Pang S.W., Lee Y.L. 2006. Impact of urban temperature on energy consumption of Hong Kong, Energy, 31, 14, pp 2623-2637,

Futcher JA, Kershaw T, Mills G, 2013. Urban form and function as building performance parameters, Building and Environment, 62, 112-123

Georgescu M, Chow W.T.L., Wang Z.H., Brazel A, Trapido-Lurie B, Roth M, Benson-Lira V. 2015. Prioritizing urban sustainability solutions: coordinated approaches must incorporate scaledependent built environment induced effects, Environ. Res. Lett. 10, 6, 061001

Griffiths GM, et al., 2005. Change in mean temperature as a predictor of extreme temperature change in the Asia-Pacific region. International Journal of Climatology, 25, pp. 1301-1330

Han, J., Yang, W., Zhou, J. et al. (2009). A comparative analysis of urban and rural residential thermal comfort under natural ventilation environment, Energy and Buildings, 41, 139-145

Hardin G, 1968. The tragedy of the commons, Science, New Series, 162, 3859 (Dec. 13, 1968), pp. 1243-1248

Hebbert M, Jankovic V. 2013. Cities and climate change: the precedents and why they matter, Urban Studies, 50, 1332-1347

Heschong L. 1979. Thermal Delight in Architecture, Cambridge, MA: MIT Press

Hitchings R, Lee S.-J. 2008. Air conditioning and the material culture of routine human encasement: the case of young people in Singapore, Journal of Material Culture, 13, 251-265

Hung T, Uchihama D, Ochi S, Yasuoka Y. 2006. Assessment with satellite data of the urban heat island effects in Asian mega cities, International Journal of Applied Earth Observation and Geoinformation, 8, 34-48

Indraganti M. 2010a. Adaptive use of natural ventilation for thermal comfort in Indian apartments, Building and Environment, 45, 1490-1507

Indraganti M. 2010b. Behavioural adaptation and the use of environmental controls in summer for thermal comfort in apartments in India, Energy and Buildings, 42, 1019-1025

IPCC, 2013. Climate Change 2013: The Physical Science Basis. Contribution of Working Group I to the Fifth Assessment Report of the Intergovernmental Panel on Climate Change. Cambridge University Press, Cambridge, United Kingdom and New York, NY, USA, 1535 pp.

Isaac, M. and van Vuuren, D.P. 2009. Modeling global residential sector energy demand for heating and air conditioning in the context of climate change, Energy Policy, 37, 507-521

Johansson E, Thorsson S, Emmanuel R, Krüger E. 2014. Instruments and methods in outdoor thermal comfort studies - The need for standardization, Urban Climate, 10, 346-366

Kalvelage K, Passe U, Rabideau S, Takle ES. 2014. Changing climate: The effects on energy demand and human comfort, Energy and Buildings, 76, 373-380 
Karyono TH, Heryanto S, Faridah I. 2015. Air conditioning and the neutral temperature of the Indonesian university students, Architectural Science Review, 58, 2, 174-183

Klein Tank, et al., 2006. Changes in daily temperature and precipitation extremes in central and South Asia, Journal of Geophysical Research, 111, D16105, DOI: 10.1029/2005JD006316

Kumar KK, Kamala K, Rajagopalan B, Hoerling MP, Eischeid JK, Patwardhan SK, Srinivasan G, et al. 2010. The once and future pulse of Indian monsoonal climate. Climate Dynamics, 36(11-12), pp. 2159-2170. doi:10.1007/s00382-010-0974-0

Lee, K.Y. 2009. The East Asian way - with air conditioning, New Perspectives Quarterly, 26(4), 111120, http://www.digitalnpq.org/archive/2009 fall 2010 winter/16 yew.html.

Lemonsu A, et al. 2013. Evolution of the Parisian urban climate under a global changing climate, Climatic Change, 116, 679-692

Lenzuni P, Freda D, Del Gaudio M, 2009. Classification of thermal environments for comfort assessment, Annals of Occupational Hygiene, 53, 4, 325-332

Lin T.-P., 2016. "Management of shading and public places," In, R Emmanuel (ed.), Urban Climate Challenges in the Tropics: Rethinking Design Opportunities, London: Imperial College Press, pp. 49-78

Lott FC, Christidis N, Stott PA. 2013. Can the 2011 East African drought be attributed to humaninduced climate change? Geophysical Research Letters, Geophys. Res. Lett., 40, 6, pp. 11771181, doi:10.1002/grl.50235

Lucon O., D. Ürge-Vorsatz, A. Zain Ahmed, H. Akbari, P. Bertoldi, L.F. Cabeza, N. Eyre, A. Gadgil, L.D.D. Harvey, Y. Jiang, E. Liphoto, S. Mirasgedis, S. Murakami, J. Parikh, C. Pyke, and M.V. Vilariño, 2014: Buildings. In: Climate Change 2014: Mitigation of Climate Change. Contribution of Working Group III to the Fifth Assessment Report of the Intergovernmental Panel on Climate Change [Edenhofer, O., R. Pichs-Madruga, Y. Sokona, E. Farahani, S. Kadner, K. Seyboth, A. Adler, I. Baum, S. Brunner, P. Eickemeier, B. Kriemann, J. Savolainen, S. Schlömer, C. von Stechow, T. Zwickel and J.C. Minx (eds.)]. Cambridge University Press, Cambridge, UK and New York, NY, USA.

Manton MJ, et al., 2001. Trends in extreme daily rainfall and temperature in southeast Asia and the South Pacific: 1916-1998. International Journal of Climatology, 21, 269-284

Mills G. 2006. Progress toward sustainable settlements: a role for urban climatology, Theoretical and Applied Climatology, 84, 1, pp. 69--76

Ng E. 2016. In, R Emmanuel (ed.), "Urban air ventilation in high density cities in the Tropics," Urban Climate Challenges in the Tropics: Rethinking Design Opportunities, London: Imperial College Press, pp. 79-110

Nguyen A.-T, Tran Q.-B, Tran D.-B, Reiter S. 2011. An investigation on climate responsive design strategies of vernacular housing in Vietnam, Building and Environment, 46, 2088-2106

Parkinson T, de Dear R. 2015. Thermal pleasure in built environments: physiology of alliesthesia, Building Research \& Information, 43, 3, pp 288-301

Perera N, Emmanuel R. 2016. A "Local Climate Zone" based approach to urban planning in Colombo, Sri Lanka, Urban Climate, http://dx.doi.org/10.1016/j.uclim.2016.11.006

Pozas BM, González FJN, 2016. Hygrothermal behaviour and thermal comfort of the vernacular housings in the Jerte Valley (Central System, Spain), Energy and Buildings, 130, pp. 219-227

Rajapaksha U, Hyde R. 2012. Barriers to and opportunities for advanced passive cooling in subtropical climates, Architectural Science Review, 55, 1, 49-60 
Rao YP, 1981. "The climate of the Indian sub-continent," in, Takahashi, K., et al., (eds.), Climates of Southern and Western Asia. World Survey of Climatology, vol. 9, Amsterdam: Elsevier Scientific Publishing, pp. 67-82

Revi A, et al., 2014. Towards transformative adaptation in cities: The IPCC's Fifth Assessment, Environment and Urbanization, 26, 1, 11-28

Rosenzweig C, Solecki W, Hammer SA, Mehrotra S. 2010. Cities lead the way in climate-change action, Nature, 21, 467, 909-911

Rosenzweig C, Solecki W, Romero-Lankao P, Mehrotra S, Dhakal S, Bowman T, Ali Ibrahim S. 2015. ARC3.2 Summary for City Leaders. Urban Climate Change Research Network. Columbia University. New York.

Roth $M, 2007$. Review of urban climate research in (sub)tropical regions, International Journal of Climatology, 27, 1859-1873

Rubio-Bellido C, Pulido-Arcas J.A, Cabeza-Lainez J.M. 2015. Adaptation strategies and resilience to climate change of historic dwellings, Sustainability, 7, pp. 3695-3713.

See L, Mills G, Ching J. 2015. Community initiative tackles urban heat, Nature, 526, p. 43

Sekhar SC, 2016. Thermal comfort in air-conditioned buildings in hot and humid climates - why are we not getting it right? Indoor Air, 26, 138-152

Sillmann J, Kharin VV, Zwiers FW, Zhang X, Bronaugh D. 2013. Climate extreme indices in the CMIP5 multi-model ensemble. Part 2: Future climate projections. Journal of Geophysical Research, Atmospheres. doi:10.1002/jgrd.50188

Sivak M. 2009. Potential energy demand for cooling in the 50 largest metropolitan areas of the world: Implications for developing countries, Energy Policy, 37, 1382-1384

Steane M.A., Steemers K (eds.), 2004. Environmental Diversity in Architecture, Routledge, ISBN-10: $041531478 \mathrm{X}$

Stewart ID, Oke TR. 2012. Local climate zones for urban temperature studies. Bulletin of American Meteorological Society, 93, 1879-1900

Thorsson S, Lindberg F, Eliasson I, Holmer B, 2007. Different methods for estimating the mean radiant temperature in an outdoor urban setting, Int. J. Climatol. 27, pp. 1983-1893

Ürge-Vorsatz D, et al., 2015. Heating and cooling energy trends and drivers in buildings, Renewable and Sustainable Energy Reviews, 41, 85-98

Velders GJM, Fahey DW, Daniel JS, McFarland M, Andersen SO. 2009. The large contribution of projected HFC emissions to future climate forcing, PNAS, 106 (27), pp. 10949-10954

Wang X, Liao J, Zhang J, Shen C, Chen W, Xia B, Wang T. 2014. A numeric study of regional climate change induced by urban expansion in the Pearl River Delta, China, Journal of Applied Meteorology and Climatology, 53, 2, 346-362

Wilhite H. 2009. The conditioning of comfort, Building Research \& Information, 37, 1, 84-88

Yan Z, et al., 2002. Trends of extreme temperatures in Europe and China based on daily observations. Climatic Change, 53, 355-392

Yau YH, Pean H.L., 2014. The performance study of a split type air conditioning system in the tropics, as affected by weather, Energy and Buildings, 72, 1-7

Yu J, Ouyang Q, Zhu Y, Shen H, Cao G, Cui W. 2012. A comparison of the thermal adaptability of people accustomed to air-conditioned environments and naturally ventilated environments, Indoor Air, 22, 2, 110-118 
Zivin JG, Neidell M, 2014. Temperature and the allocation of time: Implications for climate change, Journal of Labor Economics, 32, 1, pp. 1-26, http://dx.doi.org/10.1086/671766 